\title{
Frank M. Andrews: A Pioneer in Social Indicators and Social Reporting
}

\author{
Alex C. Michalos
}

Received: 1 May 2014 / Accepted: 5 May 2014 /Published online: 22 May 2014

(C) Springer Science+Business Media Dordrecht and The International Society for Quality-of-Life Studies

(ISQOLS) 2014

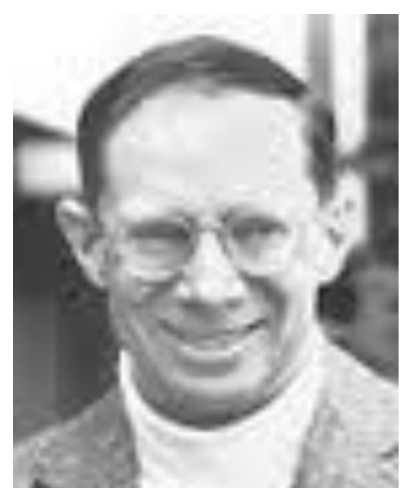

Frank Meredith Andrews (1935-1992) was a pioneer in studies of social indicators of wellbeing or quality of life research. He received a Bachelor's degree from Dartmouth College in 1957 and a doctorate from the University of Michigan in 1962. In 1959 he joined the Institute for Social Research at the University of Michigan, was named Research Scientist there in 1976 and in 1990 he received the University's Distinguished Research Scientist Award.

His magnum opus with Steven Withey (Andrews and Withey 1976) is a frequently cited classic in the field and the Andrews and Withey Delightful-Terrible Scale has been a basic building block for other standardized measures. The lead article in the first issue of Social Indicators Research was written by Andrews and Withey (1974) and it was the most frequently cited citation classic from the 1974 to 2003 period (Michalos 2005). Remarkably, in the first 30 years of publication of that journal, Andrews coauthored no less than 7 papers out of 34 that became citation classics (Andrews and Withey 1974; Andrews and McKennell 1980; Abbey and Andrews 1985; Andrews

\footnotetext{
A. C. Michalos $(\bowtie)$

University of Northern British Columbia, 463 13th Street, Brandon, Manitoba R7A 4P9, Canada e-mail: Michalos@brandonu.ca
} 
1974; Andrews and Crandall 1976; Andrews and Inglehart 1979; McKennell and Andrews 1980). In Michalos (2005) a citation classic was defined as an article with a total citation rate in the top $2.4 \%$ of all cited articles in the journal, i.e., with a rate of about three standard deviations above the mean of all articles in the journal.

By the end of his relatively short life (57 years), he was the author or editor of more than a dozen books and monographs, and 55 journal articles and book chapters. He was a member of the Editorial Board of Social Indicators Research from 1979 until his death, and his manuscript assessments were always carefully and constructively written. He was known as a warm and helpful teacher at Michigan, and was an active participant in the development and maintenance of the ISR's Summer Institute in survey research. The Frank M. Andrews Summer Institute Fellowship was established in 1992 to recognize his scholarly achievements and devotion to teaching.

In the announcement of his death in Social Indicators Research, the Editor wrote that his friends "shared his excitement with our research field, his keen insights and warm personality in our conferences over the past 20 years. I am, in Frank's terms, delighted to have been able to know him, and to lose him now is indeed terrible" (Michalos 1993).

\section{References}

Abbey, A., \& Andrews, F. M. (1985). Modeling the psychological determinants of life quality. Social Indicators Research, 16, 1-34.

Andrews, F. M. (1974). Social indicators of perceived life quality. Social Indicators Research, 1, 279-299.

Andrews, F. M., \& Crandall, R. (1976). The validity of measures of self-reported well-being. Social Indicators Research, 3, 1-19.

Andrews, F. M., \& Inglehart, R. F. (1979). The structure of subjective well-being in nine western societies. Social Indicators Research, 6, 73-90.

Andrews, F. M., \& McKennell, A. C. (1980). Measures of self-reported well-being: their affective, cognitive and other components. Social Indicators Research, 8, 127-155.

Andrews, F. M., \& Withey, S. B. (1974). Measures of perceived life quality: results from several national surveys. Social Indicators Research, 1, 1-26.

Andrews, F. M., \& Withey, S. B. (1976). Social indicators of well-being. New York: Plenum Press.

McKennell, A. C., \& Andrews, F. M. (1980). Models of cognition and affect in perception of well-being. Social Indicators Research, 8, 257-298.

Michalos, A. C. (1993). Announcement. Social Indicators Research 29:v.

Michalos, A. C. (Ed.). (2005). Citation classics from social indicators research. Dordrecht: Springer. 